\title{
INSTITUTIONAL JUDICIAL REFORM EXPERIENCES IN BELGIUM: NEW BODIES GOVERNING THE JUDICIARY
}

\author{
DR. STEFAAN VOET \\ $\&$ \\ PROF. DR. EM. MARCEL STORME \\ Institute for Procedural Law, Ghent University
}

\begin{abstract}
In February 2013, the Ministry of Justice of Luxembourg proposed a major reform of the judicial system. One of the proposals is to create a National Justice Council, after the example of the Belgian High Council of Justice. This paper gives an overview of the recent institutional judicial reforms in Belgium by analysing the new bodies governing the Judiciary: the High Council of Justice, the Belgian Judicial Training Institute, the Advisory Council for Magistrates, The Commission for the Modernisation of the Judiciary, the General Council of the Partners of the Judiciary and the forthcoming Disciplinary Courts. Each time the composition and competences of the body concerned are discussed. The conclusion is that there is a profusion of bodies with different, sometimes overlapping, competences leading to an overflow of advices.
\end{abstract}

\section{TABLE OF CONTENTS}

I. Introduction

II. High Council of Justice

III. Belgian Judicial Training Institute

IV. Advisory Council for Magistrates

V. Commission for the Modernisation of the Judiciary

VI. General Council of the Partners of the Judiciary

VII. Judicial Discipline

VIII. Some Critical Remarks

Annex. Article 151 of the Belgian Constitution 


\section{INTRODUCTION}

In February 2013, the Ministry of Justice of Luxembourg proposed a major reform of the judicial system. ${ }^{1}$ One of the proposals is to create a National Justice Council (Conseil National de la Justice) designed to protect the independence of the Judiciary and the good administration of justice. ${ }^{2}{ }^{3}$ According to the press report, ${ }^{4}$ this Council would be responsible for recruiting, nominating and promoting magistrates, ${ }^{5}$ disciplinary proceedings, establishing judicial ethics rules, regulating the judicial organisation, promoting and protecting justice, receiving and handling complaints on the functioning of the Judiciary and making recommendations improving this functioning. The Council would consist of magistrates and non-magistrates.

The proposal explicitly refers to the Belgian High Council of Justice. ${ }^{6}$ It is true that in Belgium some of the aforementioned missions are performed by this Council, while others are entrusted to separate institutions. This paper analyses these new bodies governing the Judiciary. $^{7}$

\section{High Council of JuSTiCE ${ }^{8}$}

In the mid 1990's, six young Belgian girls were kidnapped, four of whom were murdered. The atrocities were committed by a man named Marc Dutroux. ${ }^{9}$ A number of shortcomings in the Dutroux case caused widespread discontent in Belgium with the country's justice system and the functioning of its law enforcement agencies. The reform of the Judiciary was catapulted up the political agenda in April 1998, when Dutroux, while being transferred to a court house without handcuffs, managed to escape. He was caught a few hours later. In the aftermath of the case, several reform proposals of the judicial system were announced, focusing on a more qualitative, efficient, transparent and human system. With respect to the magistracy, the elimination of the so-called "political appointments", on the basis of which somebody was directly appointed magistrate based on his or her political preferences, more than on his or her capacity and suitability to carry out the office, and the introduction of an external control of the Judiciary, were the central points.

\footnotetext{
${ }^{1}$ François Biltgen présente les avant-projets de loi portant organisation du Conseil national de la Justice et de la Cour suprême, www.mj.public.lu/actualites/2013/02/Cour_supreme/index.html, last accessed on 07.05.2013.

${ }^{2}$ Avant-projet de loi portant organisation du Conseil national de la Justice [Proposal to Create a National Justice Council], www.mj.public.lu/actualites/2013/02/Cour_supreme/APL_Conseil_national_de_la_Justice_25_fevrier_2013.pdf, last accessed on 07.05.2013.

${ }^{3}$ Another proposal is to create a Supreme Court (Avant-projet de loi portant organisation de la Cour suprême [Proposal to Create a Supreme Court], www.mj.public.lu/actualites/2013/02/Cour_supreme/APL_Cour_supreme_25_fevrier_2013.pdf, last accessed on 07.05.2013). This topic falls outside the scope of this paper.

4 Dossier de presse. Conseil national de la Justice. Cour supreme, 27.02.2013, www.mj.public.lu/actualites/2013/02/Cour_supreme/Dossier_de_presse_reforme_Justice.pdf, last accessed on 07.05.2013.

${ }^{5}$ These are judges and officers of the office of the Public Prosecutor.

${ }^{6}$ Proposal to Create a National Justice Council, supra note 2, at 35-37.

${ }^{7}$ This paper is based on a national report for a conference "Judicial Reforms in Luxembourg and Europe" at the Max Planck Institute Luxembourg for International, European and Regulatory Procedural Law on 10.06.2013.

${ }^{8}$ www.csj.be/fr (French) - www.csj.be/nl (Dutch), last accessed on 14.05.2013.

${ }^{9}$ http://en.wikipedia.org/wiki/Marc_Dutroux, last accessed on 08.05.2013.
} 
The reform was called the "Octopus-reform": ${ }^{10}$ a comprehensive and far-reaching reform of the Judiciary and the law enforcement agencies. Two aspects of this reform are relevant in this context: the amendment of Article 151 of the Belgian Constitution on judicial independence, ${ }^{11}$ and the creation of a High Council of Justice. ${ }^{12}$

Before 1998, the principle of judicial independence, ${ }^{13}$ a cornerstone of every democratic state, was an unwritten norm in Belgium. Only 1998, it was laid down in Article 151, $\$ 1$ of the Constitution. This provision stipulates: "judges are independent in the exercise of their jurisdictional competences. The public prosecutor is independent in conducting individual investigations and prosecutions, without prejudice to the right of the competent minister to order prosecutions and to prescribe binding directives on criminal policy, including policy on investigations and prosecutions".

The constitutional foundations of the High Council of Justice (Hoge Raad voor de Justitie; Conseil supérieur de la Justice; Hoher Justizrat) are laid down in Article 151, §2 et seq. of the Constitution, while detailed rules on its composition and competences are written down in Part II of the Judicial Code regarding judicial organisation. ${ }^{14}$ The High Council of Justice is not a part of the Judiciary, as third branch of government. It is not a court in the sense of Article 40 of the Belgian Constitution. ${ }^{15}$ Article 151, $\$ 2$ explicitly states that the High Council of Justice respects the independence of the Judiciary. Neither does the High Council belongs to the Executive or the Legislative branch. It is an institution sui generis with own competences serving as an intermediary, or a bridge, between the Judiciary on the one hand and the Executive and the Legislative Branch on the other hand.

${ }^{10}$ The name octopus, or 'eight-legs', refers to the fact that eight political parties concluded the "Octopusagreement".

11 For an English version of the Belgian Constitution see www.dekamer.be/kvvcr/pdf_sections/publications/constitution/grondwetEN.pdf, last accessed on 10.05.2013. The English text of Article 151 of the Constitution is added as an annex to this paper.

${ }^{12}$ Modification à la Constitution [Amendment of the Constitution], 20.11.1998, Moniteur Belge 24.11.1999, 37679 and Loi modifiant certaines dispositions de la deuxième partie du Code judiciaire concernant le Conseil supérieur de la Justice, la nomination et la désignation de magistrats et instaurant un système d'évaluation pour les magistrats [Act Amending Certain Provisions of Part II of the Judicial Code Regarding the High Council of Justice, the Nomination and Appointment of Magistrates and Introducing an Evaluation System for Magistrates], 22.12.1998, Moniteur Belge 02.02.1999, 2922. See F. Delpérée, Octopus, genèse et réalisations, in: X., Une justice en crise: premières réponses, p. 89-104 (Brussels: Bruylant 2002); J. Laenens and M.L. Storme (eds.), In de ban van Octopus, 145 p. (Antwerp: Kluwer, 2000) and X., Octopus - de justitiehervorming, 7 Orde van de Dag 3 (1999).

${ }^{13}$ For a recent and thorough analysis see B. Allemeersch, A. Alen and B. Dalle, Judicial Independence in Belgium, in: A. Seibert-Fohr (ed.), Judicial Independence in Transition. Strengthening the Rule of Law in the OSCE Region, 307-356 (Heidelberg: Springer, 2011).

${ }^{14}$ Articles 259bis-1 to 259bis-22 Judicial Code. See D. de Bruyn, Le Conseil supérieur de la Justice, 5929 Journal des tribunaux 401 (1999); I. Dupré, De Hoge Raad voor de Justitie. Het nieuwe huis van vertrouwen?, 42 Rechtskundig Weekblad 1507 (1998-1999); K. Kloeck, De Hoge Raad voor de Justitie. Motor voor een humane en communicatieve justitie?, in: L. Dupont and F. Hutsebaut (eds.), Herstelrecht tussen toekomst en verleden. Liber Amicorum Tony Peters, 357-381 (Leuven: Universitaire Pers Leuven, 2001); Ch. Matray, Le Conseil supérieur de la Justice: de quelques perplexités, in: X., Une justice en crise: premières réponses, 153190 (Brussels: Bruylant, 2002); Ch. Matray, De werkzaamheden van de Hoge Raad voor de Justitie, in: X., Naar een positieve deontologie, 35-62 (Brussels: Bruylant, 2009); S. Raes and J. Laenens, Justitie hervormd, 208 p. (Antwerp: Maklu, 2000); M.L. Storme (ed.), De Hoge Raad voor de Justitie na vier jaar gewogen, 224 p. (Bruges: die Keure, 2005) and M. Verdussen (ed.), Le Conseil supérieur de la justice, 262 p. (Brussels: Bruylant, 1999).

15 “Judiciary power is exercised by the courts. Court decisions are executed in the name of the King”. 
The High Council of Justice is composed of a Dutch-speaking and French-speaking College, each with 22 members. Their term of office runs for 4 years, once renewable. Together the 44 members make up the General Assembly of the High Council of Justice. Each college is composed of 11 magistrates and officers of the Public Prosecutor's office and 11 non-magistrates. The former are elected by their peers, while the latter are appointed by the Belgian Senate. There have to be at least 4 lawyers with at least 10 years of professional experience, 3 professors with at least 10 years of professional experience and 4 members with at least 10 years of relevant (legal, economic, administrative, social or scientific) experience. ${ }^{16}$ The composition of the High Council is published in the Belgisch Staatsblad, the Official Gazette of Belgium. The Belgian constitutioner wanted to create a depoliticised institution with a clear language parity, underlining that the Belgian justice system is (still) a federal matter, and complete equality of magistrates and non-magistrates, thereby excluding any form of corporatism. ${ }^{17}$

Out of the General Assembly 4 members are elected that make up the Board of the High Council of Justice. The Board is responsible for coordinating the activities of the High Council and the Colleges. The Presidency of the High Council is rotated, so that the 4 Board members each serve one year as President.

Within each College two Committees are composed: a Nomination and Appointment Committee, composed of 14 members of which 7 magistrates and 7 non-magistrates, and an Advisory and Investigatory Committee, composed of 8 members of which 4 magistrates and 4 non-magistrates. The Dutch-speaking and French-speaking members of the two Nomination and Appointment Committees make up the United Nomination and Appointment Committee. The Dutch-speaking and French-speaking members of the two Advisory and Investigatory Committees make up the United Advisory and Investigatory Committee.

Organisation Chart of the High Council of Justice:

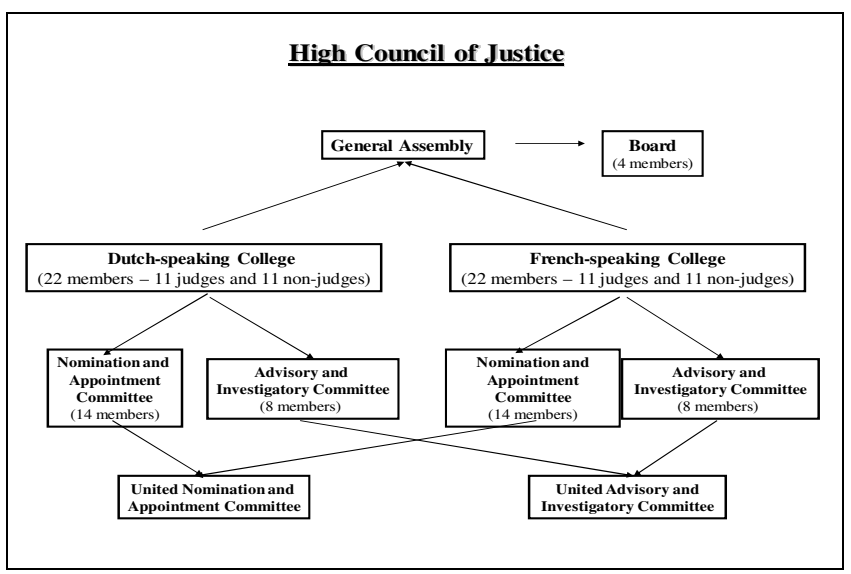

The competences of the High Council of Justice are listed in Article 151, §3 of the Constitution. This is a non-limitative list. According to Article 151, §3, last paragraph a law to be adopted by a specific majority can determine other competences of the Council.

\footnotetext{
${ }^{16}$ In the past public servants, journalists, clerks, and auditors were member of the High Council of Justice.

17 J. Laenens, K. Broeckx, D. Scheers and P. Thiriar, Handboek gerechtelijk recht, $3^{e}$ editie, 176 (Antwerp: Intersentia, 2012).
} 
The competences can be divided in three categories: the nomination and appointment of magistrates (A), external control over the functioning of the Judiciary (B), and advising policy makers to improve the functioning of the Judiciary $(\mathrm{C})$.

\section{A. The nomination and appointment of magistrates ${ }^{18}$}

The Nomination and Appointment Committees are responsible for organising the exams to become eligible for judge or officer of the Public Prosecutor's office. For candidates with at least one year of professional experience, there is a written and oral comparative entrance exam giving access to a judicial traineeship. ${ }^{19}$ For lawyers with more professional experience, the Committees organise a professional capabilities exam, ${ }^{20}$ giving immediate access to a vacancy. Finally, for lawyers with at least 20 years of professional experience, the Committees organise an oral evaluation exam, also giving instant access to a vacancy.

As mentioned above, one of the key aspects of the "Octopus-reform" and the creation of the High Council of Justice, was to end the so-called "political appointments", on the basis of which somebody was directly appointed magistrate based on his or her political preferences, more than on his or her capacity and suitability to carry out the office. Today, the Executive still appoints magistrates, but this is based on an objective motivation by the Nomination and Appointment Committees of the High Council of Justice. ${ }^{21}$ The nomination process takes place as follows. After a round of advice, an objective comparison of the candidates is drawn. If a candidate gains two-thirds of the votes of the competent Nomination and Appointment Committee, he or she is nominated for the vacancy.

Allemeersch et al. point out that this nomination (and promotion) process is still criticised in the sense that there remains a potential degree of political and ideological influence. The problem seems to be the composition of the High Council, half of its members being appointed by the Senate. There is a concern that these politically appointed members are led by their political or ideological beliefs. ${ }^{22}$ Former members of the High Council rebut this criticism

\footnotetext{
18 "Article 151, $\$ 3:(..) 1^{\circ}$ the nomination of candidates for appointment as [justice of the peace, judge of a court and Supreme Court judge] or for appointment as officer of the public prosecutor's office; $2^{\circ}$ the nomination of candidates for an appointment [as first president of the Supreme Court, first president of an appeal court or first president of a lower court] and to the position of head of the public prosecutor's office; $3^{\circ}$ access to the position of judge or of officer of the public prosecutor's office; (...) $5^{\circ}$ drafting of general profiles for the positions referred to in $2^{\circ} ;(\ldots)$ ". For a detailed overview of the selection, appointment and promotion processes see B. Allemeersch, A. Alen and B. Dalle, supra note 13, at 317. The rules are laid down in Articles 259ter to 259septies Judicial Code.

${ }^{19}$ To become an officer of the Public Prosecutor's office, there is a short traineeship of 18 months. To become a judge, there is a long traineeship of 36 months.

${ }^{20}$ To become an officer of the Public Prosecutor's office, one needs 5 years of professional experience. To become a judge, one needs 10 years of professional experience.

${ }^{21}$ The Executive can reject a nomination but it has to state its reasons for doing so. The High Council then has 15 days to issue a new nomination. This hardly happens, although there is one notable case (see H. Lamon, Strafblad hinderpaal voor benoeming tot rechter, 266 Juristenkrant 8 (2013)). In 2012, a lawyer from Antwerp applies for a position as judge in the Court of First Instance in Antwerp. He is nominated as the best candidate by the Dutchspeaking Nomination and Appointment Committee. The minister of Justice refuses to appoint him since in 2011 he was convicted for a hit-and-run crime. The vacancy goes back to the High Council of Justice. The same Committee nominates the lawyer again. It finds that having a clean record is not a condition to become judge. Moreover, the candidate disclosed his conviction. Again the minister puts aside the decision of the Committee. The lawyer then starts a procedure before the Council of State. The Council rejects his claim and rules that somebody who is convicted for a hit-and-run crime engenders a presumption that he or she lacks the necessary qualities that are expected from a judge (Conseil d'État [Council of State], 04.02.2013 (Dieter Geernaert v. Belgische Staat), nr. 222.363, www.raadvst-consetat.be/?page=caselaw_results\&lang=fr, last accessed on 05.05.2013).

${ }^{22}$ B. Allemeersch, A. Alen and B. Dalle, supra note 13, at 320.
} 
since they never observed any political or ideological influence by the non-magistrates. In any event, the diverse composition of the Nomination and Appointment Committees functions as a safeguard. $^{23}$

\section{B. External control over the functioning of the Judiciary ${ }^{24}$}

The Advisory and Investigatory Committees of the High Council of Justice conduct an external control over the functioning of the Judiciary, over and above the existing internal mechanisms. It does so by a centralised complaints system, as well as extensive court audits. It has to be underlined that the Committees never have the right to intervene in ongoing cases. $^{25}$ All advices and recommendations of the Committees, as discussed hereafter, are approved by the General Assembly and notified to the minister of Justice, the Chamber of Representatives, the Senate, the Presidents of all Courts and all Public Prosecutors and Attorney-Generals. ${ }^{26}$

The Advisory and Investigatory Committees receive complaints on the functioning of the Judiciary. ${ }^{27}$ Everyone (citizens, residents, lawyers, judges, public servants, etc.) can make a complaint. By law, complaints must be written, signed and dated and must disclose the identity of the complainant. The following complaints are inadmissible: complaints that are the subject of criminal or disciplinary proceedings, complaints regarding the content of a judicial decision, complaints that are already dealt with and do not contain new elements, complaints that can be addressed by using an existing procedural mechanism (e.g., appeal), and complaints that are apparently unfounded. If other authorities are competent to deal with the complaint, the Committee will refer the complainant. An accepted complaint is transmitted to the hierarchical superior of the magistrate or member of the Judiciary against whom the complaint is made. The magistrate or member concerned is notified and can submit oral or written comments. The Committee can request additional information from all magistrates to whom it has notified the complaint. At the end, the complainant is informed about the outcome. The High Council of Justice can formulate recommendations and propose actions to improve the functioning of the Judiciary. It can also inform the disciplinary authorities when it considers that disciplinary rules were violated. Once a year, every Advisory and Investigatory Committee drafts a report about the steps which have been taken as a result of the complaints received. These are integrated in the annual report of the High Council of Justice.

According to the 2011 Annual Report, ${ }^{28} 274$ complaints were received that year. ${ }^{29} 307$ complaints were treated. Most of these complaints criticised a judicial decision ${ }^{30}(25,79 \%)$ or the slowness of a judicial proceeding (14,74\%). Others had to do with communication $(10 \%)$,

\footnotetext{
${ }^{23}$ B. Aerts and R. Boone, Hoge Raad voor de Justitie na 10 jaar. 95 procent objectieve benoemingen is het hoogst haalbare', 207 Juristenkrant 8 (2010).

${ }^{24}$ Article 151, \$3: (...) $7^{\circ}$ general surveillance on and the promoting of the use of means of internal control; $8^{\circ}$ to the exclusion of all disciplinary and criminal competences: - the receiving and the following-up of complaints relating to the operation of the judiciary; - the conducting of an enquiry on the operation of the judiciary".

${ }^{25}$ Article 259bis-17 Judicial Code.

${ }^{26}$ Article 259bis-18 Judicial Code.

${ }^{27}$ Article 259bis-15 Judicial Code.

${ }^{28}$ Conseil supérieur de la Justice, Rapport Annuel 2011. Approuvé par l'assemblée générale le 30 mai 2012 [Annual Report 2011. Approved by the General Assembly on 30.05.2012], www.csj.be/sites/5023.fedimbo.belgium.be/files/press_publications/r0033f.pdf, last accessed on 10.05.2013.

${ }^{29}$ In 2010, the High Council received 347 complaints, in 2009: 385, in 2008: 323 and 2007: 341.

${ }^{30}$ This is not only a court decision, but also a decision of the Public Prosecutor to dismiss a case.
} 
judicial actors (e.g., lawyers or notaries) (7,37\%), and the lack of respect by a judge or clerk $(7,11 \%) .10,26 \%$ of the complaints did not relate to the functioning of the Judiciary. Only 52 (or $37,41 \%$ ) of the 307 complaints were founded (the majority (30 complaints) related to the slowness of a judicial proceeding). For the other complaints, the High Council was not competent $(63,42 \%)$, or dismissed them as unfounded $(62,59 \%)$.

The United Advisory and Investigatory Committee also can conduct a special inquiry into the operation of the Judiciary, so-called court audits. ${ }^{31}$ It can do so sua sponte, ${ }^{32}$ at the request of the minister of Justice or at the request of a majority of the members of the Chamber of Representatives or the Senate. The audit is outsourced to the President of the Court concerned who has to report to the Committee. In exceptional cases, ${ }^{33}$ the audit is conducted by the Committee itself, under the guidance of a member-magistrate. The Committee can visit the Court concerned and can make all necessary assessments. It can also consult and copy closed court files, ${ }^{34}$ and hear members of the Judiciary, who can make statements without breaching their professional secrecy. At the end of the inquiry, the Committee drafts a report that has to be approved by two thirds of its members.

Since the start of its activities in 2000, the High Council of Justice, through its United Advisory and Investigatory Committee, conducted 9 court-audits. ${ }^{35}$ For example in 2010 a court audit was conducted of the commercial courts, and in particular the Brussels Commercial Court. ${ }^{36}$ The audit was ordered by the minister of Justice, and the immediate cause were possible irregularities committed by the President of the Brussels Commercial Court in selecting and appointing lay judges and experts. ${ }^{37}$ In its final report, the Committee made some recommendations regarding the functioning and managing of lay judges (in particular in bankruptcy proceedings) and court appointed experts.

\footnotetext{
${ }^{31}$ Article 259bis-16 Judicial Code.

${ }^{32}$ A simple majority is needed in the United Advisory and Investigatory Committee.

${ }^{33}$ On the request of the minister of Justice, or when, in light of the subject of the inquiry, it is not advisable to charge the President of the Court concerned with the inquiry.

${ }^{34}$ On 27.03.2013, a proposal was submitted to the Chamber of Representatives to allow the United Advisory and Investigatory Committee to consult non-closed court files (Chambre des représentants de Belgique, Proposition de Loi modifiant le Code judiciaire en vue d'octroyer à la Commission d'avis et d'enquête réunie du Conseil supérieur de la Justice la compétence de consulter des dossiers judiciaires non clôturés [Proposal to Amend the Judicial Code to Allow the United Advisory and Investigatory Committee to Consult Non-Closed Court Files], 27.03.2013, DOC 53 2728/001, www.dekamer.be/FLWB/PDF/53/2728/53K2728001.pdf, last accessed on 09.05.2013).

35 See www.csj.be/fr/search/apachesolr_search?filters=type\%3Apublication\%20tid\%3A27, last accessed on 05.05.2013. The following courts and offices of the Public Prosecutor were audited: the office of the Public Prosecutor in Brussels (2001 and 2006), the criminal courts of Charleroi (2002), the Brussels Court of Appeal (2004, 2008 and 2009), the Brussels Police Court (2008), the commercial courts (2010) and the labor courts of Namur/Dinant (2011).

${ }^{36}$ Conseil supérieur de la Justice, Audit des Tribunaux de Commerce. Rapport approuvé par la Commission d'avis et d'enquête réunie le 16 décembre 2010 [Audit of the Commercial Courts. Report Approved by the United Advisory and Investigatory Committee on 16.12.2010], www.csj.be/sites/5023.fedimbo.belgium.be/files/press_publications/r0028f.pdf, last accessed on 10.05.2013.

${ }^{37}$ In January 2013, the President of the Brussels Commercial Court was convicted by the Brussels Court of Appeal of forgery and breach of the professional secrecy.
} 
C. Advising policy makers to improve the functioning of the Judiciary ${ }^{38}$

Finally, the United Advisory and Investigatory Committee of the High Council of Justice provides advice to policy makers on the better functioning of the Judiciary. ${ }^{39}$ This involves mainly the issuing of opinions on legislative proposals and policy memoranda to the minister of Justice, the Chamber of Representatives or the Senate. The Committee advises on the general functioning of the Judiciary, on the appropriation of the available resources, and legislative proposals having repercussions on the functioning of the Judiciary. The Committee can make inquiries and can ask members of the Judiciary, via their hierarchical superiors, for information. The advices are not binding.

Since 2000, the Committee drafted 87 advices, ${ }^{40}$ in various domains: financial penalties and legal costs in criminal cases (2013), the forthcoming judicial reform and the mobility of judges (2013), conditional release (2012), crime victim registration (2012), the reform of the Assise Courts (2011), court appointed experts (2011), the European order for payment procedure (2011), the introduction of a Family Court (2010), the introduction of a collective procedure/class action (2009), the evaluation of judges (2006), the recoverability of attorney's fees (2006), etc. It also drafted 17 recommendations, ${ }^{41}$ for example on the correction of judgments (2010), communication and reception in courts (2010), disclosing the identity of judges to litigants (2009), financial management of registries (2008), the remuneration of court appointed experts (2006), etc.

In 2011, Allemeersch, Alen and Dalle evaluated the three competences of the High Council as follows:

"first, it has indeed made the judicial selection process more objective. Through its professionalism, it has increased the attractiveness of a judicial career and the credibility of the recruitment process. It is beyond doubt that this has had a very positive effect on the overall quality and aptitude of newly appointed judges. Second, it has proven a reliable and skillful advisor to the policymakers, bringing added value to the policy debate and commanding respect from all other stakeholders. As far as its third objective is concerned, that of exercising external control over the justice system, there is still room for improvement. While the High Council has undertaken some remarkable audit investigations into the performance of certain courts - their conclusions often being extensively covered by the national media - it lacks the necessary instruments to conduct thorough investigations in case of serious irregularities and to follow up adequately on its findings and recommendations. Also, there are problems with information streams, such that the committees dealing with the application for promotion of a certain judge often are not aware of disciplinary or criminal investigations against that same judge or even of relevant findings in the report of the Council's own advice and audit committees. Finally, it has turned out that the process in which citizens can turn to the High Council with complaints about the justice system is not very accessible, too cumbersome and not efficient". ${ }^{2}$

\footnotetext{
${ }^{38}$ Article 151, $33:(\ldots) 6^{\circ}$ voicing of advice and of proposals concerning the general operation and organization of the judiciary (...)”.

${ }^{39}$ Article 259bis-12 Judicial Code.

40 See www.csj.be/fr/search/apachesolr_search?filters=type $\% 3$ Apublication\%20tid\%3A24, last accessed on 05.05.2013.

41 See www.csj.be/fr/search/apachesolr_search?filters=type $\% 3$ Apublication $\% 20$ tid $\% 3 \mathrm{~A} 29$, last accessed on 05.05.2013.

${ }^{42}$ B. Allemeersch, A. Alen and B. Dalle, supra note 13, at 316.
} 
In its 2011 Coalition Agreement the government intends to reform the role of the High Council of Justice, and in particular its external control missions. ${ }^{43}$ Already in December 2011, the High Council issued an opinion on this intention. ${ }^{44}$ The Council proposes to expand and facilitate its power to conduct a special inquiry into the operation of the Judiciary. It wants to be able to conduct such an inquiry not only in case of structural and organisational dysfunctions, but also in case of individual dysfunctions. The inquiry should always be conducted by the Council, in which the President of the Court concerned can be involved to undertake specific investigations. The Council should also have access to ongoing judicial investigations and nonclosed (civil and criminal) court cases, without permission of the President of the Court concerned. It should be possible to organise a hearing. The final report should give insight in the structural and specific recommendations, and the Council should be able to decide to whom it should be sent. From an organisational point of view, the Council proposes to create a new Commission for External Control and Advice (replacing the United Advisory and Investigatory Committee), consisting of 4 committees (Audit Committee, Special Inquiries Committee, Dutch-speaking Complaints Committee and an French-speaking Complaints Committee).

\section{III.BELGIAN JUDICIAL TRAINING INSTITUTE ${ }^{45}$}

In 2007, the Belgian Judicial Training Institute (Instituut voor Gerechtelijk Opleiding; Institut de Formation Judiciaire; Institut für Ausbildungen im Gerichtswesen) was created. ${ }^{46}$ It started its activities in January 2009. The Institute only organises the professional training of the members of the Judiciary and the exchange of professional experience. Training for the exams to become eligible for judge or officer of the Public Prosecutor's office ${ }^{47}$ does not fall under its scope. The Institute wants to contribute to an efficient justice system by developing the professional competencies of the members of the Judiciary.

Like the High Council of Justice, the Judicial Training Institute is an independent institution. According to the Consultative Council of European Judges, ${ }^{48}$ the training of judges should be entrusted:

43 Accord de Gouvernement 01.12.2011 [Coalition Agreement 01.12.2011], www.premier.be/sites/all/themes/custom/tcustom/Files/Accord_de_Gouvernement_1er_decembre_2011.pdf, 139, last accessed on 08.05.2013.

${ }^{44}$ Conseil supérieur de la Justice, Avis d'office sur le renforcement des compétences du Conseil supérieur de la Justice en matière de contrôle externe, et particulièrement en matière d'enquête particulière. Approuvé par l'assemblée générale le 21 décembre 2011 [Advice On the Reinforcement of the Competences of the High Council of Justice Regarding External Control and in Particular the Special Inquiry. Approved by the General Assembly on 21.12.2011], www.csj.be/sites/5023.fedimbo.belgium.be/files/press_publications/a0075b.pdf, last accessed on 10.05.2013.

45 www.igo-ifj.be/, last accessed on 10.05.2013 For a brochure in English see www.iojt.org/iojt2/library/IOJTarticle.pdf, last accessed on 10.05.2013.

${ }^{46}$ Loi sur la formation judiciaire et portant création de l'Institut de formation judiciaire [Act on Judicial Training and the Creation of the Judicial Training Institute], 31.01.2007, Moniteur Belge 02.02.2007, 5481. See E. Van Den Broeck, Het Instituut voor gerechtelijke opleiding: op weg naar een integraal ontwikkelings-en opleidingsbeleid voor de magistraten en personeelsleden van de rechterlijke orde, 46 Orde van de Dag 81 (2009) and G. Van Haegenborgh, Het Instituut voor gerechtelijke opleiding: een eerste kennismaking, 2 Ius \& Actores 95 (2008).

${ }^{47}$ See supra.

${ }^{48}$ Consultative Council of European Judges, Opinion $n^{\circ} 4$ of the Consultative Council of European Judges (CCJE) to the attention of the Committee of Ministers of the Council of Europe on appropriate initial and inservice training for judges at national and European levels, 27.11.2003, https://wcd.coe.int/ViewDoc.jsp?Ref=CCJE(2003)OP4\&Sector=secDGHL\&Language=lanEnglish\&Ver=origina 
"to a special body responsible for drawing up the curriculum, providing the training and supervising its provision. (...) The European Charter on the Statute for Judges [of the Council of Europe $\left.{ }^{49}\right]$ (...) states that any authority responsible for supervising the quality of the training program should be independent of the Executive and the Legislature and that at least half its members should be judges. (...) This highlights the key importance attaching to the independence and composition of the authority responsible for training and its content. This is a corollary of the general principle of judicial independence. Training is a matter of public interest, and the independence of the authority responsible for drawing up syllabuses and deciding what training should be provided must be preserved. Those responsible for training should not also be directly responsible for appointing or promoting judges".

The Institute consists of three bodies: ${ }^{50}$ the Board of Directors, the Executive Management and the Scientific Committee. ${ }^{51}$ The Board of Directors approves the annual action plan, budget and staffing plan as proposed by the Management. It also controls the activities of the Management. The Board consists of 16 members $(8$ Dutch-speaking and 8 French-speaking members). The members are the 2 Presidents of the Nomination and Appointment Committees of the High Council of Justice, the Director-General of the Institute, the President of the Commission for the Modernisation of the Judiciary, ${ }^{52} 3$ leading civil servants of the education department of the Flemish/French/German-speaking Communities, a representative of the Ministry of Justice, 2 judges, 2 officers of the Public Prosecutor's office ${ }^{53}$ and 4 other members of the Judiciary. The Board appoints a President among its members.

The Executive Management (consisting of a President and two Vice-Presidents) is responsible for everyday management. Amongst other activities, it is mainly in charge of the conception of the training programs; the preparation of the annual action plan, budget and staffing plan; the expenditure of the budget and concluding public contracts and mutual agreements and cooperation protocols with other training institutions, organisations and associations. The members of the Management are nominated by the High Council of Justice and appointed by the minister of Justice. They cannot be a member of the High Council of Justice and are barred from other professional activities.

At the request of the Executive Management and the Board of Directors, the Scientific Committee provides recommendations and advice on the training policy of judges and other members of the Judiciary, the training programs and their organisation, and the pedagogical methods to be used. The Committee counts 21 members (with the exception of the President, 10 Dutch-speaking and 10 French-speaking members): 2 judges, 2 officers of the office of the Public Prosecutor, 4 other members of the Judiciary, 2 lawyers, 8 academics, and 2 members of the Training Institute of the Federal Government.

\footnotetext{
$1 \&$ BackColorInternet=FEF2E0\&BackColorIntranet=FEF2E0\&BackColorLogged $=\mathrm{c} 3 \mathrm{c} 3 \mathrm{c} 3$, last accessed on 11.05.2013.

${ }^{49}$ See www.coe.int/t/dghl/monitoring/greco/evaluations/round4/European-Charter-on-Statute-of-Judges_EN.pdf, last accessed on 11.05.2013.

${ }^{50}$ There is also a Dutch-speaking and French-Speaking Commission for the Evaluation of the Judicial Traineeship (see supra) (Articles 42-43 Act of 31.01.2007).

${ }^{51}$ Articles 9-37 Act of 31.01.2007.

52 See infra.

${ }^{53}$ The judges and the officers of the Public Prosecutor's office are nominated by the High Council of Justice.
} 
Judicial training is defined as: ${ }^{54}$

- the initial training of members of the Judiciary, i.e. training provided during the judicial traineeship or at the commencement of employment;

- the permanent training provided during the career aiming at developing the professional competence, ${ }^{55}$

- $\quad$ and career counseling in preparation of a future position.

An overview of all offered trainings can be found on the website of the Institute. ${ }^{56}$ Judges and officers of the office of the Public Prosecutor can follow internal trainings on, for example, MS office 2010, coaching in management, civil procedure, tax law, the new Belgian Code on Nationality, accountancy, etc. It speaks for itself that members of the Judiciary also can follow external trainings organised by universities and publishing companies, as long as these trainings are recognised by the Institute. The Institute also offers language courses and elearning. ${ }^{57}$ It is also possible to follow judicial trainings abroad or trainings offered by the European Judicial Training Network, ${ }^{58}$ of which the Institute is a member. ${ }^{59}$ The Institute even offers grants to magistrates wanting to follow a traineeship abroad.

\section{IV.ADVISORY COUNCIL FOR MAGISTRATES ${ }^{60}$}

In 1999, the Advisory Council for Magistrates (Adviesraad van de Magistratuur; Conseil consultatif de la magistrature; Beirat der Magistratur) was created. ${ }^{61}$ Only in May 2006, it started its activities. The General Assembly of the Council counts 44 members. ${ }^{62}$ The 22 Dutch-speaking members make up the Dutch-speaking College, while the 22 Frenchspeaking members form the French-speaking College. Each College consists of 4 appellate judges, 2 officers of the office of the Public Prosecutor in the courts of appeal, 8 first instance judges, 4 officers of the office of the Public Prosecutors in the first instance courts, 2 justices of the peace and 2 police judges. Like the magistrates of the High Council of Justice, the magistrates are elected by their peers and their term of office runs for 4 years, once renewable. Out of each College 3 members (a President, Vice-President and secretary) are elected that make up the Board of the Council. The Presidency of the Council rotates between the 2 Presidents every 2 year (starting with the oldest). The Board prepares the meetings of the General Assembly, coordinates its activities and executes its decisions.

\footnotetext{
${ }^{54}$ Article 3 Act of 31.01.2007.

${ }^{55}$ During a judicial term, every judge or officer of the office of the Public Prosecutor can participate at 5 permanent trainings offered by the Institute (Article 4 Act of 31.01.2007).

${ }^{56}$ www.igo-ifj.be/fr/content/formations, last accessed on 10.05.2013.

${ }^{57}$ For example, there is an online course on the implementation of the European Convention on Human Rights.

58 www.ejtn.net/en/, last accessed on 10.05.2013.

${ }^{59}$ Some examples of international judicial trainings: 'International Judicial Cooperation in Criminal Matters in Practice: European Arrest Warrant and MLA simulation', 'EU Law on Industrial Emission', 'A Systematic Study on the European Judicial Area in Civil and Commercial Matters', etc.

60 www.arm-ccm.be/portal/page/portal/ARM/Startpagina _ _ (French) - www.armccm.be/portal/page/portal/ARM/Startpagina (Dutch), last accessed on 14.05.2013.

${ }^{61}$ Loi instaurant un Conseil consultatif de la magistrature [Act Creating an Advisory Council for Magistrates], 08.03.1999, Moniteur Belge 19.03.1999, 8801. See S. Raes and J. Laenens, Justitie hervormd, 208 p. (Antwerp: Maklu, 2000).

${ }^{62}$ Although this is not stipulated in the Act of 08.03.1999, the Council also set up 10 working groups (and sometimes sub working groups) on: the functioning of the Council, the social statute of magistrates, communication, the career of magistrates, financial statute of magistrates, discipline and deontology, defederalisation, measuring the workload of magistrates, the introduction of a family court and the pension plan for magistrates.
} 
The Advisory Council for Magistrates considers itself as the one and only interlocutor between the Judiciary and the Executive and Legislative, for which it invokes three reasons: the Council is created by the legislature, its members come from all branches of the Judiciary, and they are elected. ${ }^{63}$ Its mission is to advice the minister of Justice, the Chamber of Representatives or the Senate, and to consult with them, regarding everything relating to the statute, rights and working conditions of judges and officers of the office of the Public Prosecutor. ${ }^{64}$ The Council acts at the request of the minister, the legislative chambers or on its own motion. The minister of Justice notifies all (accepted) legislative proposals regarding the missions of the Council, to the Council. ${ }^{65}$ Its advices are not binding.

Since 2006, the Council drafted around 20 advices, ${ }^{66}$ in various domains: the forthcoming judicial reform and the mobility of judges (2013), the pension plan for magistrates (2012), the introduction of a Family Court (2011), new disciplinary rules for judges (2010 and 2011), leave conditions for judges (2009), etc. An initiative that caught the eye of the media, was its 2012 deontological guide for magistrates, which it drafted together with the High Council of Justice. ${ }^{67}$ The guidelines, which are not to be considered as a binding code of discipline, are inspired by and based on the Judicial Ethics report of the European Network of Councils for the Judiciary. ${ }^{6}$

\section{COMMISSION FOR THE MODERNISATION OF THE JUdICIARY ${ }^{69}$}

In $2006,{ }^{70}$ the Belgian Parliament adopted an act creating the Commission for the Modernisation of the Judiciary (Commissie voor de modernisering van de rechterlijke orde; Commission de Modernisation de l'Ordre judiciaire) and the General Council of the Partners of the Judiciary (Algemene Raad van de Partners van de Rechterlijke Orde; Conseil général des partenaires de l'Ordre judiciaire $).^{71}$ The former is established within the Ministry of the Justice. This link is purely functional, since the Commission acts independently. The Commission gives an annual account to Parliament, the minister of Justice and the High Council of Justice.

The Commission consists of a President, a Vice-President and 6 members, all of whom are appointed by the minister of Justice for a 6-year term, renewable once. The

\footnotetext{
${ }^{63}$ Conseil consultatif de la magistrature, Rapport d'Activité 2010-2012. Approuvé par l'Assemblée générale du Conseil consultatif de la magistrature du 26 novembre 2012 [Activities Report 2010-2012. Approved by the General Assembly of the Advisory Council for Magistrates on 26.11.2012], 4, www.armccm.be/portal/page/portal/ARM/Mededelingen, last accessed on 10.05.2013.

${ }^{64}$ Article 5, §1 Act of 08.03.1999.

${ }^{65}$ Article 5, \$4 Act of 08.03.1999.

${ }^{66}$ See www.arm-ccm.be/portal/page/portal/ARM/Adviezen, last accessed on 14.05.2013.

${ }^{67}$ Conseil supérieur de la Justice et Conseil consultatif de la magistrature, Guide pour les magistrats. Principes, valeurs et qualités [Magistrates Guide. Principles, Values and Qualities], http://www.armccm.be/portal/page/portal/ARM/Mededelingen/guide_magistrats.pdf, accessed on 14.05.2013.

68 European Network of Councils for the Judiciary, Judicial Ethics Report 2009-2010, www.encj.eu/images/stories/pdf/ethics/judicialethicsdeontologiefinal.pdf, last accessed on 14.05.2013.

${ }^{69}$ www.cmro-cmoj.be/fr (French) - www.cmro-cmoj.be/nl (Dutch), last accessed on 14.05.2013.

${ }^{70}$ Loi instaurant la Commission de Modernisation de l'Ordre judiciaire et le Conseil général des partenaires de l'Ordre judiciaire [Act Creating the Commission for the Modernisation of the Judiciary and the General Council of the Partners of the Judiciary], 20.07.2006, Moniteur Belge 01.09.2006, 43773. See H. Van Bossuyt, Brengt de oprichting van een nieuwe Commissie en een nieuwe Raad de oplossing op de weg naar een moderne justitie?, 15 Rechtspraak Antwerpen Brussel Gent 1180 (2006).

${ }^{71}$ This Council will be discussed hereafter.
} 
President and Vice-President are a judge and an officer of the office of the Public Prosecutor. One has to be Dutch-speaking, the other French-speaking. They should have fulfilled important functions relating to the management of the Judiciary. During their office, they are barred from other professional activities. The 6 members (3 Dutch-speaking and 3 Frenchspeaking members) are 2 magistrates (a judge and an officer of the office of the Public Prosecutor), 2 other members of the Judiciary, and 2 senior civil servants (one of them belong to the Ministry of Justice). The Commission also has a secretariat.

In general, the Commission is responsible for any action aimed at the modernisation of the management of the Judiciary. In particular it has the following statutory missions: ${ }^{72}$

- leading a general reflection on the modernisation of the management of the Judiciary;

- organising and leading a reflection on the structures of the managing bodies of the Judiciary;

- working out projects on the harmonisation, improvement and modernisation of judicial management;

- inventing experimental projects on the management of the Judiciary, to be worked out on the federal or local level;

- guiding experiments on the transfer of jurisdiction in the context of an administrative decentralisation;

- offering methodological support in experimental projects related to the management of the Judiciary;

- proposing methods that optimise the use of means for the functioning of the Judiciary;

- and setting up and leading a network for the exchange of information between the central administration of the Ministry of Justice and the presidents of the different courts.

The Commission's projects are classified in 6 themes: ${ }^{73}$ finance (e.g., legal costs), personnel (e.g., job specification, absenteeism, psychosocial stress, administrative managers), communication (e.g., e-groups and electronic notification of court decisions), management tools (e.g., measuring the workload), organisation (of, for example, the juvenile court of Antwerp, the Court of Appeal of Ghent, the office of the public prosecutor in Brussels and Charleroi) and working tools (e.g., the projects on JustScan and Knowledge Tree). Each project has a specific goal and time limit, which are laid down in a partnership agreement. Each project consists of 4 phases: a preparatory phase, fieldwork, reporting and follow up. Partnership agreements were concluded with, for example, the Court of Appeal of Ghent (November 2011), the Court of First Instance of Antwerp on the juvenile court (September 2010), the Ministry of Justice on legal costs in criminal cases (June 2009), the office of the public prosecutor in Brussels (February 2009), etc.

\footnotetext{
${ }^{72}$ Article 3 Act of 20.07.2006.

${ }^{73}$ www.cmro-cmoj.be/fr/realisations/realisations, last accessed on 14.05.2013.
} 


\section{General Council of the Partners of the Judiciary}

The act creating the Commission for the Modernisation of the Judiciary also established the General Council of the Partners of the Judiciary. ${ }^{74}$ This Council is responsible for proposing initiatives on the modernisation of the management of the Judiciary to the Commission, for which it acts as a sounding board.

The Council consists of different judicial actors: a Supreme Court judge, an officer of the office of the Public Prosecutor in the Supreme Court, 4 judges, 2 officers of the office of the Public Prosecutor, a justice of the peace, a police judge, a senior civil servant of the Ministry of Justice, 2 lawyers, 2 bailiffs, 2 notaries, 4 other members of the Judiciary (e.g., a clerk), 2 external members, and the President and Vice-President of the Commission for the Modernisation of the Judiciary. Two members of the High Council of Justice also belong to the Council, however without right to vote. Among its members, the Council elects a President and Vice-President.

\section{JUDICIAL DISCIPLINE}

The current rules on judicial discipline, dating from $2002{ }^{75}$ are laid down in the Judicial Code. ${ }^{76}$ In 2013 (or 2014), they will change radically. In April 2013, the Belgian Senate approved a legislative proposal to amend the Judicial Code regarding judicial discipline. ${ }^{77}$ The proposal is currently pending before the Chamber of Representatives.

The law currently makes a distinction between light and severe disciplinary sanctions. ${ }^{78}$ The former are a warning or reprimand. The latter are (in the first degree) withholding pay or suspension, and (in the second degree) dismissal or removal from judicial office. In case of light disciplinary sanctions, disciplinary proceedings are initiated by the hierarchical superior of the magistrate or member of the Judiciary concerned, who also conducts the disciplinary investigation and who is also competent to effectively impose a light sanction. ${ }^{79}$ In case of severe disciplinary sanctions, the investigation is conducted by the National Discipline Council. ${ }^{80}$ This Council is composed of a Dutch-speaking and Frenchspeaking Chamber and counts among its members judges, officers of the office of the Public Prosecutor, clerks, lawyers and law professors. The Council investigates the facts and gives a non-binding advice on the sanction to be imposed. Disciplinary proceedings take place before

\footnotetext{
${ }^{74}$ Articles 10-12 Act of 20.07.2006.

${ }^{75}$ Loi modifiant la deuxième partie, livre II, titre $V$ du Code judiciaire relatif à la discipline et rapportant la loi du 7 mai 1999 modifiant le Code judiciaire en ce qui concerne le régime disciplinaire applicable aux membres de l'Ordre judiciaire [Act Amending the Judicial Code Regarding Judicial Discipline], 07.07.2002, Moniteur Belge 14.08.2002, 34919. See G. Londers, De tucht en de deontologie van de magistraat, in: S. Lust and P. Luypaers (eds.), Tucht en deontologie. (In)effectiviteit van het tuchtrecht ter handhaving van de waardigheid van het ambt, 327-355 (Bruges: die Keure, 2007).

${ }^{76}$ Articles 398-427quater Judicial Code.

77 Sénat de Belgique, Proposition de loi modifiant les dispositions du Code judiciaire relatives à la discipline [Proposal to Amend the Judicial Code Regarding Judicial Discipline], 30.04.2013, DOC 5 1067/9, www.senate.be/www/webdriver?MItabObj=pdf\&MIcolObj=pdf\&MInamObj=pdfid\&MItypeObj=application/pd $\mathrm{f} \& \mathrm{MIvalObj}=83889807$, last accessed on 09.05.2013. For a brief analysis see X., Tucht door Senaatscommissie, 268 Juristenkrant 14 (2013).

${ }^{78}$ Article 405 Judicial Code.

${ }^{79}$ Articles 410, 411, §1 and 412, §1 Judicial Code.

${ }^{80}$ Article 409 Judicial Code.
} 
the First Chamber of the Court of Appeal ${ }^{81}$ or the First Chamber of the Supreme Court, ${ }^{82}$ that take into account the non-binding advice of the National Discipline Council. In case a sanction is imposed, there is a possibility of appeal. ${ }^{83}$ In most cases the appeal is brought before the United Chambers or the First Chamber of the Supreme Court.

The pivotal role of the hierarchical superior of the magistrate or member of the Judiciary concerned is considered to be an obstacle. ${ }^{84}$ Some of them struggle with their disciplinary tasks. Sometimes it is perceived that disciplinary proceedings take place behind closed doors, and lack any transparency. Some investigations seem like personal vendettas. ${ }^{85}$ Moreover, the advices of the National Discipline Council are non-binding and sometimes remain a dead letter. ${ }^{86}$

In the future all members of the Judiciary will be subject to a uniform (and simplified) disciplinary proceeding. The distinction between light and severe disciplinary sanctions will be maintained, although the division between severe sanctions in the first and second degree will disappear. Two non-permanent Disciplinary Courts will be created, one for the Dutchspeaking region (having its seat in Ghent) and one for the French-speaking region (having its seat in Namur). By creating two independent disciplinary courts, Parliament wants to reinforce confidence in the Judiciary. These Courts will be composed of two specialised judges and a member of the same court of the magistrate or member of the Judiciary concerned (called an assessor). A president of a Bar Council (to be appointed by the Flemish or French and German speaking Bar Council) will have a consultative voice. There will also be two non-permanent Disciplinary Courts of Appeal (both having their seat in Brussels).

Disciplinary proceedings will still be initiated by the hierarchical superior, at his own motion, or on the basis of a complaint of a private individual or the High Council of Justice. The investigation has to be finished within three months. If not, the magistrate concerned will be able to bring the case before the Disciplinary Court that will summon the hierarchical superior to finish the investigation. The hierarchical superior remains competent to impose a light disciplinary sanction. This decision can be appealed before the Disciplinary Court. In case of a severe disciplinary sanction, the case will be transferred to the Disciplinary Court. The Court will have the possibility to appoint an examining magistrate that can take all necessary measures, hear witnesses, organize confrontations, etc. After the examining

\footnotetext{
${ }^{81}$ Article 412, §2 Judicial Code. This is the case for disciplinary proceedings against the presidents of the courts of first instance, first instance judges, justices of the peace and police judges.

${ }^{82}$ This is the case for disciplinary proceedings against the presidents of the courts of appeal and appellate judges.

${ }^{83}$ Article 415 Judicial Code.

${ }^{84}$ Sénat de Belgique, Proposition de loi modifiant les dispositions du Code judiciaire relatives à la discipline [Proposal to Amend the Judicial Code Regarding Judicial Discipline], 07.06.2011, DOC 5 1067/1, 1-2, www.senate.be/www/webdriver?MItabObj=pdf\&MIcolObj=pdf\&MInamObj=pdfid\&MItypeObj=application/pd $\mathrm{f} \& \mathrm{MIvalObj}=83887436$, last accessed on 09.05.2013.

${ }^{85}$ For example, in 2012 and 2013 there was a big crisis in the office of the Public Prosecutor in Antwerp as a result of Belgium's biggest diamond fraud case ever. One disciplinary investigation after the other was conducted against the Public Prosecutor and Attorney-General of Antwerp, who declared an open war against each other.

${ }^{86}$ For example, in 2009 the First Chamber of the Court of Appeal of Ghent removed a judge in the Court of First Instance of Bruges from judicial office, since he never rendered a decision in time and even withheld court files. The judge appealed the decision at the Supreme Court. To everybody's surprise, the Supreme Court reversed the decision of the Court of Appeal and decided only to withhold his pay for 2 months (Cour de Cassation [Court of Cassation], 24.11.2009 (PMJAEV), nr. D090001N, http://jure.juridat.just.fgov.be/?lang=fr\&jur=1, last accessed on 14.05.2013). The Supreme Court explicitly disregarded the advice of the National Discipline Council, which it considered too severe.
} 
magistrate has finished his or her investigation, or in case the Court does not appoint such a magistrate, the case will be handled by the Court. Its decision can be appealed before the Disciplinary Court of Appeal.

\section{SOME CRITICAL REMARKS}

Undoubtedly, all of the aforementioned councils, commissions, and institutes were created with good intentions, since they aim to contribute to the good, efficient and transparent functioning of the Judiciary, in order to reinforce public confidence. After the Dutroux case, the Belgian legislature wanted to make a clean sweep with the past. The High Council of Justice was established as a bridge between the Judiciary and the Executive and Legislature. Its composition of magistrates and non-magistrates is unique.

In the wake of this, and over the past years, other bodies governing the Judiciary were established: the Belgian Judicial Training Institute, the Advisory Council for Magistrates, the Commission for the Modernisation of the Judiciary and the General Council of the Partners of the Judiciary. Very recently, the Belgian Senate adopted a proposal amending the rules on judicial discipline and attributing jurisdiction to two new Disciplinary Courts. All of them are shaped taking into account the (complex) linguistic situation in Belgium.

However, some critical remarks can be made. First of all it cannot be denied that today there is a profusion of bodies with different, sometimes overlapping, competences leading to an overflow of advices. One author noted for example that the General Council of the Partners of the Judiciary is an advisory body advising the Commission for the Modernisation of the Judiciary, which is another advisory body that can advise the minister of Justice, but only after an advice of the High Council of Justice..${ }^{87}$ In other words, all of this might be, as the Germans say, zuviel des Guten (too much of a good thing). ${ }^{88}$

It is true that the High Council of Justice put an end to the so-called "political appointments". The second author of this paper championed for this abolition when he was a member of the Belgian Senate from 1977 to $1981{ }^{89}$ However, this did not mean that at the time there were no good candidates to become magistrate, yet that sometimes very good candidates did not get chance because they lacked political support. The most poignant critique concerns the fact that in this new system nobody can be called to account. Before, one could interpellate the minister of Justice in Parliament in case of an improper appointment or promotion. Today, this is not possible anymore.

The United Advisory and Investigatory Committee of the High Council of Justice regularly conducts special inquiries into the operation of the Judiciary, so-called court audits. However, these audits are rare, habitually initiated as a result of a specific problem or dysfunction, very limited in scope, and carried out on an ad hoc basis, i.e. in the absence of a general legal framework. Following the Netherlands, Belgium has a good functioning, fiveyearly, visitation system for its universities. A similar general and permanent audit system could be developed for the Judiciary. The audit teams could consist of a magistrate, a lawyer and a former litigant. This could be coupled with the installation of a general, permanent, and

\footnotetext{
${ }^{87}$ See H. Lamon, Nieuwe adviescultuur bij justitie, 143 Juristenkrant 2 (2007).

${ }^{88}$ In total, all these bodies count more than 120 members.

${ }^{89}$ See his parliamentary intervention on 19.01.1978 (R. De Corte, J. Laenens, M. Storme, P. Taelman and K. Broeckx, Storme terecht, 89-105 (Deurne: Kluwer, 1995)).
} 
non-political manager for the Judiciary, operating next to the minister of Justice, and reporting directly to Parliament about his or her findings.

Finally, all bodies governing the Judiciary revolve (or should revolve) around the most vital pillar of the Judiciary in a democratic state: judicial independence. Winston Churchill once said: "the principle of complete independence of the judiciary from the executive is the foundation of many things in our island life". 90 For over 30 years, the International Association of Judicial Independence and World Peace ${ }^{91}$ has been active in promoting judicial independence. Its projects can, and should be, a continuous source of inspiration for all bodies governing the Judiciary. ${ }^{92}$

\footnotetext{
${ }^{90}$ As quoted by K. Nayar, Suppression of Judges, 123 (New Delhi: Indian Book Co, 1974).

${ }^{91} \mathrm{http}: / / \mathrm{www} . j \mathrm{iwp} . \mathrm{org} /$, last accessed on 21.05.2013.

92 http://www.jiwp.org/\#!our-projects/c15zd, last accessed on 21.05.2013: New Delhi Standards (1982), Montreal Declaration (1983), and the Mont Scopus Standards (2007-2012) (see S. Shetreet and Ch. Forsyth (eds.), The Culture of Judicial Independence. Conceptual Foundations and Practical Challenges, 662 p. (Martinus Nijhoff, 2011)).
} 


\section{AnNeX. Article 151 OF The Belgian Constitution}

$\S 1$. Judges are independent in the exercise of their jurisdictional competences. The public prosecutor is independent in conducting individual investigations and prosecutions, without prejudice to the right of the competent minister to order prosecutions and to prescribe binding directives on criminal policy, including policy on investigations and prosecutions.

$\S 2$. There is one High Council of Justice for all Belgium. In the exercise of its competences, the High Council of Justice respects the independence referred to in $\S 1$.

The High Council of Justice is composed of a Dutch-speaking college and of a Frenchspeaking college. Each college comprises an equal number of members and is constituted with equal representation, on the one hand, of judges and officers of the public prosecutor's office elected directly by their peers under the conditions and in the manner determined by the law and, on the other hand, of other members appointed by the Senate by a two-thirds majority of the votes cast, under conditions established by the law.

Within each college, there is a nomination and appointment committee, as well as an advisory and investigatory committee, which are constituted with equal representation in accordance with the provision laid down in the preceding paragraph.

The law specifies the composition of the High Council of Justice, of its colleges and of their committees, as well as the conditions under which and the manner in which they exercise their competences.

$\S 3$. The High Council of Justice exercises its competences in the following areas:

$1^{\circ}$ the nomination of candidates for appointment as judge, as referred to in $\S 4$, first paragraph or for appointment as officer of the public prosecutor's office;

$2^{\circ}$ the nomination of candidates for an appointment to the positions referred to in $\S 5$, first paragraph and to the position of head of the public prosecutor's office;

$3^{\circ}$ access to the position of judge or of officer of the public prosecutor's office;

$4^{\circ}$ training of judges and of officers of the public prosecutor's office;

$5^{\circ}$ drafting of general profiles for the positions referred to in $2^{\circ}$;

$6^{\circ}$ voicing of advice and of proposals concerning the general operation and organisation of the judiciary;

$7^{\circ}$ general surveillance on and the promoting of the use of means of internal control;

$8^{\circ}$ to the exclusion of all disciplinary and criminal competences:

- the receiving and the following-up of complaints relating to the operation of the judiciary;

- the conducting of an enquiry on the operation of the judiciary.

Under the conditions and in the manner determined by the law, the competences referred to in $1^{\circ}$ to $4^{\circ}$ are assigned to the relevant nomination and appointment committee, and the competences referred to in $5^{\circ}$ to $8^{\circ}$ are assigned to the relevant advisory and investigatory committee. The law determines the cases in which and the manner in which the nomination and appointment committees and the advisory and investigatory committees exercise their competences jointly.

A law to be adopted by a majority as described in Article 4, last paragraph determines the other competences of this Council.

$\S 4$. The justices of the peace and the judges of the courts and of the Supreme Court are appointed by the King under the conditions and in the manner specified by the law.

Such appointment is made on reasoned nomination by the relevant nomination and appointment committee, by a majority of two thirds in accordance with the terms specified by 
the law and after evaluation of qualifications and aptitude. The nomination can be rejected only in the manner specified by the law and with justification.

In the case of appointment of an appeal judge or of a judge of the Supreme Court, the general assembly of the court concerned issues a reasoned opinion in the manner specified by the law, prior to the nomination referred to in the preceding paragraph.

$\S 5$. The first president of the Supreme Court, the first presidents of the appeal courts and the presidents of the lower courts are appointed to those positions by the King under the conditions and in the manner specified by the law.

Such appointment is made on reasoned nomination by the relevant nomination and appointment committee, by a majority of two thirds in accordance with the terms specified by the law and after evaluation of qualifications and aptitude. The nomination may be rejected only in the manner specified by the law and with justification.

In the case of appointment to the position of first president of the Supreme Court or of first president of an appeal court, the general assembly of the court concerned issues a reasoned opinion in the manner specified by the law, prior to the nomination referred to in the preceding paragraph.

The president of the Supreme Court, the presidents of the sections of this court, the presidents of the divisions of the appeal courts and the vice-presidents of the lower courts are appointed to their positions by the courts from their midst under the conditions and in the manner specified by the law.

Notwithstanding the provisions of Article 152, the law specifies the duration of the appointment to these positions.

$\S 6$. In the manner specified by the law, the judges, the incumbents of the positions referred to in $\S 5$, fourth paragraph and the officers of the public prosecutor's office are subject to an evaluation. 